\title{
Feature Tasawuf Ibn Arabi (Analysis of Sufistic Values in the Book of FuSuŚ Al- Hiikam)
}

\author{
Listiawati Susanti ${ }^{1}$, Amroeni ${ }^{2}$, Hasan Bakti Nasution ${ }^{2}$ \\ ${ }^{1}$ Ph.D Student in State Islamic University of North Sumatera (UINSU), Medan, Indonesia \\ ${ }^{2}$ Lecturer in State Islamic University of North Sumatera (UINSU), Medan, Indonesia
}

\begin{abstract}
The aims of this study is to find out the sufistic values in book of FuSi $\dot{S}$ Al- Hikam. This study used qualitative research. The result shows Ibn 'Arabí has nothing at all to carry the name and opinion of a philosopher or figure both Islamic and outside Islam in initiating his thinking. Even if he mentions the name or the name of one character in order to reject their opinion or compare it with the results obtained. For Fusisi al-Hikam Ibn 'Arabí to prove that the book was indeed given by the prophet directly to him.
\end{abstract}

Keywords : Tasawuf Ibn Arabi; Sufistic Values; Fu $\dot{S} u \dot{S}$ Al- Hikam

\section{Introduction}

Sufis have different spiritual experiences and achievements when doing spiritual wandering with the aim of being close to Al-Khalik. Even to express zauq that they feel is difficult to represent in the form of words, so it is not uncommon for them to use symbolic language as an expression of the spiritual achievements they have gained. Some use the term maqām and some use the term al-Faidh (delegation).

One of the Sufi leaders who uses the term al-faid al-tajallī is Shaykh Abu Bakr Muhammad ibn 'Ali who holds Muhyi al-Dín Ibn'Arabí (d. 638 H / 1240 AD). Ibn 'Arabí is a Sufi thinker who has exclusive thinking that influences the Islamic world a lot. According to him the existence of nature and the existence of Adam (human) are part of the existence of Allah, manifested in a perfect form as a divine mirror ready to receive delegation from Him. The universe is the nature of the macrocosm, while humans are the nature of the microcosm. Nature and Adam are figures manifested by Allah to show His existence, the outward form which is the place of manifestation of rūhiyah. The form of rụhiyah is from God, as the driver of manifestation lahiriyah.

Ibn 'Arabí said :

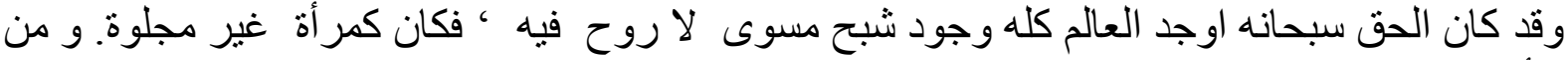

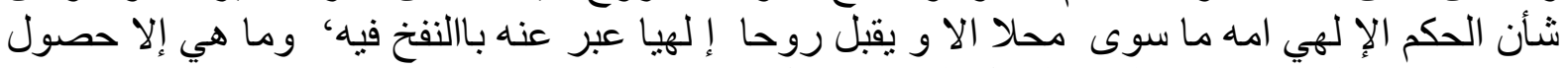
الإستعداد من تلك الصورة الصه المر اة لقبول الفيض التجل .

"When Allah SWT. want to see Himself in the greatness of His infinite name, in nature that gathers all affairs, because of Himself who is sympathized with being, and cleanses His secrets to that realm, for something that sees itself with itself as it sees itself on the other as a mirror, he cleanses it in a form that takes place and can be seen without showing Himself and tajalli."

The whole realm is like a reflecting mirror, with potential to accept the divine ruh (nafkh), and ready to receive the abundance (al-fai al-tajallí) of the daim and never lost (lam yazal wala yuzal). And so Adam is the essence of the mirror beam, and the soul of its shape, while the angel is part of the power of that form, that is, the natural form that people termed-according to he-with al-insān al-kabír. 
In paragraph above Ibn 'Arabí has demonstrated the thought of how Adam and nature are an al-insān al-agír and al-insān al-kabír. Of course many interpretations can be put forward to pin down what Ibn's will 'Arabí with those sentences. Sitting Adam as a great nature transcends the realm where he lives comes to thinking how important humans are. The nature of it is only two, divine nature and human nature. Nature became important after he was made a container of human existence. The existence of man is so great in the eyes of Allah beyond the existence of nature, though physically nature is greater than that of man. It was at least that the child of the sentence who became a development of Ibn's first sentence 'Arabí with a simple and easy understanding. While the ocean of its understanding is broadly unrefined that it declares to be the hadith of the Rasulullah.

As a thinker Ibn 'Arabí can be called a phenomenal Sufi, because he has been reconciled since childhood. For him Sufism is a choice, when other people make it runaway. Because Sufism is its scientific habitat, its expertise in this field leaves a fairly distinctive and interesting trail to analyze, namely the concepts of the language of rumuz, kinayah, tashwir, and tasybih, which can be called sign language, that religion teaches its essential message through symbols. But not only did he see verses of kauniyah and verses of kitabiyah which gave other signs of existence, also the way to form his understanding was unique. In the approach of his thinking which is patterned as maudhu 'iy, the mufradat and the number of texts that in general can be understood zhahir by him are interpreted ta'wil, even though at that time ta'wil was not a solution to the inability to use birth meanings, such as held by Sunni Syafi'i mufassir. For example the prophet Nuh complained to Allah that his people were misled by their children and property. Children are derivatives of fathers, because that means walad as an inappropriate child. It is precisely the verse that implies that what comes out of the human being is the one who misleads him, namely his thinking.

\section{Review of Literature}

\subsection{Defenition of Tasawuf}

The word tasawuf, actually already familiar in the Islamic world, although there are differences of opinion among experts about the origin of the word tasawuf, but they agree that the purpose of tasawuf is to achieve closeness with the Creator. tasawuf, which in English is called mysticism or tasawuf, began to be known as a scientific term at the end of the second century Hijri. This term comes from the word al-shafa ', which means clean or pure. Another opinion says that it comes from the word shuff, which means coarse wool, the type of fabric commonly used by Sufis and pious people before Islam as a symbol of simplicity. Besides that in Madina there was a group of students who did not have a place to live, during the night sleeping in the porch of their mosque was called the shuffah. Which of the ulama's terms of origin are taken from the tasawuf, there is no explanation, maybe both of them, given that the dimensions of life that Sufi lives and desires are both in character. According to al-Qusyairi this term does not have a language acquisition, also qiyas, but only naming it, if from the word safa or sifah it is very far from the aspect lughawi, as well as from suf because the Sufis do not use it specifically.

The word tasawuf in language is a word from the root word 'sawwafa yusawwifu tasawwufan' which means to be shufi. The word tasawuf itself is taken from the word safā, which means clean, ${ }^{1}$ then Tasawuf means to be clean. If taken from the word 'saf', it means a

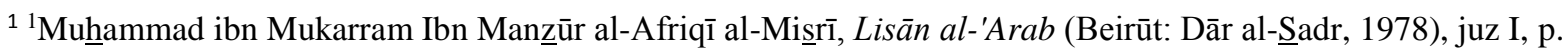
$170-176$.
} 
line, Allah likes those who fight in His ways lined up like buildings that are stacked together, or lines of worship, so that tasawuf seems to declare a Sufi to be the first line facing God and clean of heart .

In terms of understanding tasawuf is known as a scientific discipline that grows from spiritual experience that refers to the life of morality that comes from Islamic values. According to Sheikh Zakaria al-Ansari tasawuf is a knowledge that is known by its state of cleansing of the soul, purification of morals, doing amaliah inner and outer to achieve lasting happiness. Indeed, it is rather difficult to get a sufficient definition of jami and mani in making this tasawuf boundary, according to experts, due to the dimension that is the object of tasawuf knowledge that is very broad. Therefore besides the scientific terms which sometimes cannot describe the essence of tasawuf as a whole the mutasawwifin also defines Sufism with activity. Imam al-Junaid al-Baghdadi said tasawuf is the purity of muamalah', at other times he said tasawuf is the name of ten meanings, first being little in all things of the world rather than multiplying, holding their hearts to Allah rather than feeling calm to the asbab, love the sunnah worship when there is opportunity, patience for the absence of the world rather than asking and complaining, can distinguish something that will be taken, busy with Allah than everything, remembrance khafi from the whole remembrance of remembrance, seeking sincerity when overwritten by anxiety, choose sure when coming in doubt, feeling calm with Allah rather than shaking and faltering, if all these things are collected, then someone deserves to be called a Sufi, if not then he lies.

\subsection{History and Basics of Tasawuf}

As Islamic scholarship tasawuf also developed from the values that exist in Islam, both from the teachings of the Alquran Sunnah and the practices of the life of the Prophet and the narrations of the experiences of his companions, as well as the ummah before Islam, but the Sufic arguments of the ummah are not taken from argument they. Sayyid Husain Nasr explained that although some forms of tasawuf were based on the teachings of Platonism and Hermesism in fact the essence of tasawuf, his creeds, and his fundamental methods were still returned to the source of revelation that was bound to a firm bond with the spirit of Islam in formality, as its position in the Alquran which sees the most perfect judgment for tasawuf.

Sufi philosophers have built many tasawuf theories in various ideas influenced by philosophy that lived before the birth of Islam. The philosophers who became the basis of tasawuf that developed in passing can be seen from Ibn Sina (980-1037 AD) about the universe, Neo-Empidocles theories adopted by Ibn Massarah (d. 923 AD), the teachings of Hermes in the set of works of Jabir ibn Hayyan and the treatises of Ikwan al-Șafa who had a tendency to Neo Pitagoras.

In the matter of 'aqidah there is the influence of the Ruwaqiyyin group, Failun al-Yahud, Neo Platonism, and other ancient madrassas. Sufi response to opinions about psychology, physics, logic, the methods of science, the wisdom of the divine, which relates to the divine being becomes the flow of thought in the writings of the Sufis.

\subsection{Islamic Tasawuf Streams}

Tasawuf is a way to get closer to Allah, cleanse the soul, be commendable, and control worldly passions, so that the hijab is open. Achievement of closeness with Allah is something abstract and unmeasured, because that opinion in this case will be different and the method is also different.

Sunni comunnity start their Tasawuf from Sunni kalam, discuss Allah with three points of view, substance, nature, and affinity. Allah's substance is not affordable because it is not exploited in 
science. But his character and deeds are summarized in all his names, al-hayyu, al-qayyum, al-sami, al-bashir. All of this asthma ta'alluq to all mumkinat. The Mu tazili only recognize matter, there is no character. If the nature is of course qadim too, then ta addud al-qudama '. This is the cornerstone that underlies Shia Tasawuf. According to Asy'ariyah, the nature is not a substance, but not in addition to substances (غ يره هي لاو هـ), like white paper, white is not paper, but not just paper. The nature that stands on matter, the substance gets an identity from the nature. Sunni Tasawuf explores his inner strength to connect to the attributes of Allah, Tasawuf Syili explores his inner being to connect with Allah 's substance.

\section{Discussion}

\section{Sistematika Fuṣūṣ Al- Ḥikam a. Method of Writing the Book}

The book Fușus al-Hikam is the largest book of Ibn Arabi which contains the concept of 'aqidah sufiah that lived in its time and afterwards. This book puts the highest principle of the school of wahdat al-wujud with terms taken from various sources, such as the Qur'an, hadith, the science of kalam, masyaiyyah philosophy, hadithah aflatoniyah philosophy, al-ghunusiyyah al-Masihiyyah, philosophy of Jewish Philosophy, also using Ismaili terminology, batiniyah, qaramitah, Ikhwanussafa, and previous tasauf figures. But he interpreted it specifically in accordance with the thoughts of wahdat al-wujud which influenced the Sufis later in various languages, such as Arabic, Persian, Turkish, and Malay. Both in the form of essays, poems, poetry, and so on. Fușus al-Hikam.

Ibn Arabi in writing was not like the other writers who enjoyed what they wrote. In writing, following the demands of his bloated soul, the insistence of his mind was full, so he was forced to write it to escape the pressure. He said:

"In each of my writing I did not intend to write it, but often came to me al-warid from God who almost consumed me. So I will try to spill it through writing that is not writing style, not a planned pattern. I have also written about the issue of divinity that Allah has commanded in dreams, or mukasyafah."

According to șahib Nuhfat Tayib Ibn Arabi dictated three pieces of paper a day. He recounted in his writings entitled Miftah Aqfál al-Ilham, once he awoke before dawn then he woke up two people who became his scribes and he dictated up to two pieces of paper before the sun rose. ${ }^{2}$ Writing methods such as this illustrate how extraordinary speed in writing, essays that do not follow the tradition of thematic scientific writing, the writing is precisely the mixing of the premise of philosophy, philosophy, imagination and Sufi mujahadah which are all shed in deep symbols.

\section{b. Classification of Fuṣūṣ al-Hikam}

Ibn 'Arabí compiled his book in 27 pearls of wisdom as follows:

1. Wisdom of Divinity in the sentence about Adam.

Adam was created in the form of Allah. This expression is based on the hadith of the Prophet. :

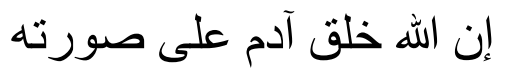

2 al-Fayumi, Ibn `Arabi, p. 22. 
Indeed, Allah created Adam based on His form. The Qur'an also says 'and Allah taught Adam al-asma 'in its entirety'.

\section{Wisdom nafsiyyah (breath of spirit) in the sentence about Syís.}

According to Bali Affandi in Syarh Fușūs al-Hikam, the name Syís means hibbatullah, the gift of Allah, and that knowledge is only devoted to Syís. Syís was chosen as the second phase because Ibn Arabi wanted to tell about the grace of Allah.According to al-Ghurab this naming fas with nafsiyyah explains that science follows the ma'lum. These are the sciences which Ibn Arabi obtained by blowing into his heart. This knowledge was inherited by the Syis , he was the first prophet to know this knowledge.

About Syís, which is called hibbatullah, according to Al-Ţabari is the gift of Allah SWT. to Adam (who was then 130 years old) as the comforter of Adam's heart because of the death of Abel killed by his brother Qabil. And Eve gave birth to Syỉs and her twin brother 'Azura (in another account the name of the Syisis's twin brother was called Hazurah) 5 years after Abel's death. Adam taught Syís the Knowledge of God, covering the times of day and night, worship of beings at all times and others. Adam in his lifetime received 10 Suhuf (sahifah), while Syïs received 50 suhuf (sahifah).

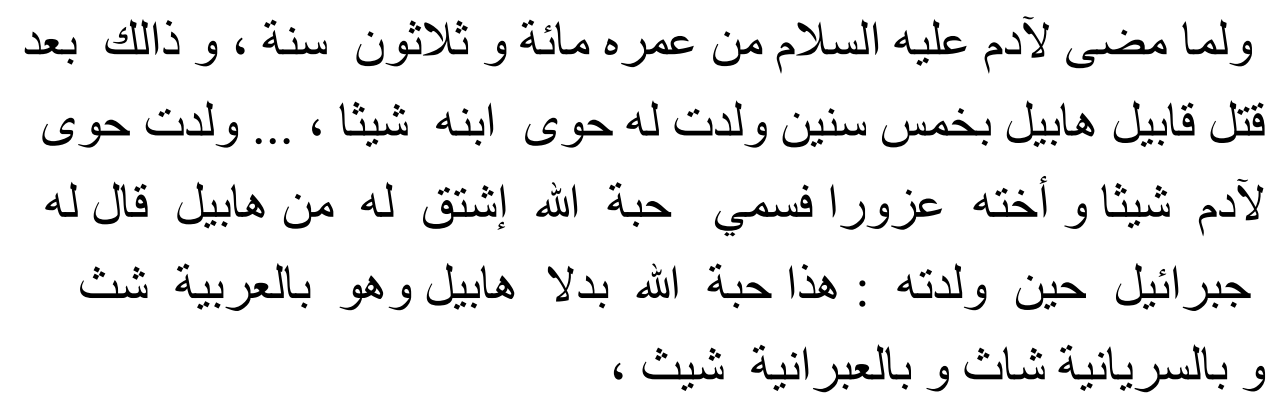

When Adam Alaihissalam was 130 years old, which was five years after the events of Qabil killing Abel, Eve gave birth to her son Syi ${ }_{i}^{\bar{S}}$.... Eve gave birth to Adam Sy ${ }^{\top} \dot{s}$ and his twin brother Azura so his son was named the gift of God in exchange for his beloved son Abel. Gabriel said to Adam during the birthday of Syis: "This is God's gift as a substitute for Abel and in Arabic called Sisy, Syriac Syāsy Language, and Syriac Hebrew.

When Adam will die, he intends to Syis that there will be a hurricane for 7 years (that is, a typhoon that drowns out those who deny in the time of Noah) and Syis learns various sciences from Adam including knowledge of future disasters. This was stated by Al-Ţabari as follows:

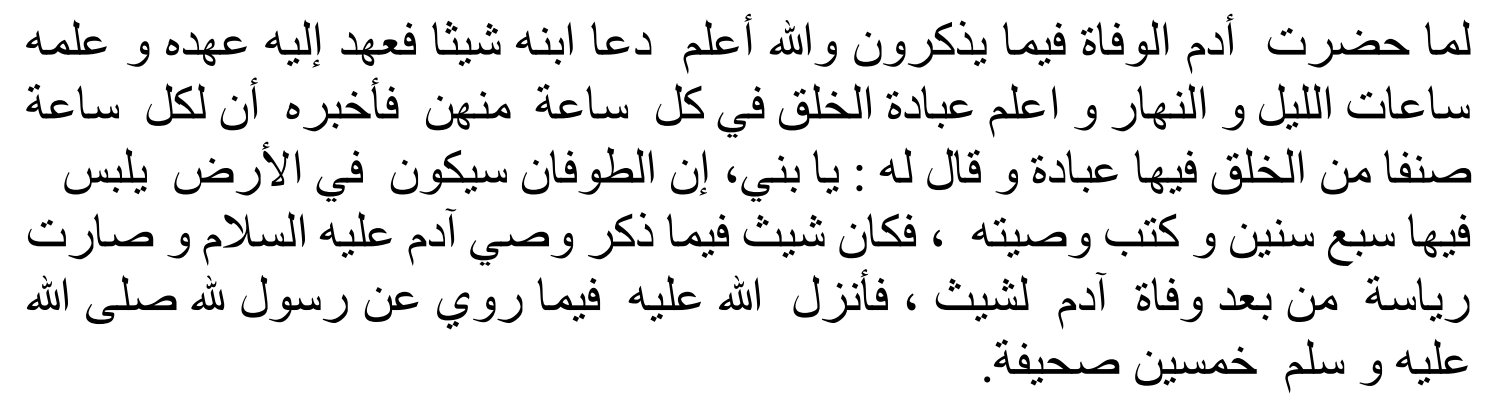

3. Wisdom subbūhiyah (Kemahasucian) in the sentence about Nūh. 
Nuh is the son of Lamak, the son of Matwashlikh, the son of Akhnukh (Idris a.). In this time of Nuh, there was a typhoon that had been mentioned to Shuhuf Syís, which Adam had left to Syís: "My child, in fact a typhoon will occur on earth which lasts for 7 years". This admonition of Adam shows the secret of the Science of Allah that has been taught in its entirety to Adam. Nuh brought his wife, three children, Hām, Sām, and Yāfits, along with the three wives of their children, they numbered 8 people. The Nuh comunnities who participated with him was saf inah Nuh was a descendant of $S y i \bar{s}$, amounting to 73 people, in addition to various kinds of plants and animals which were all in pairs.

In Faș about Nūh, Ibn 'Arabí discusses tasybīh and tanzỉh. Tasybīh comes from the word

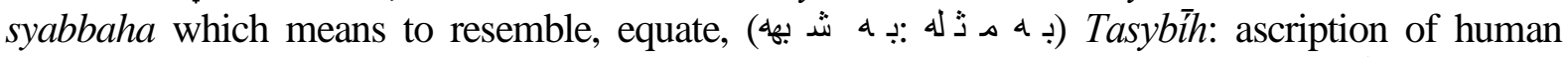

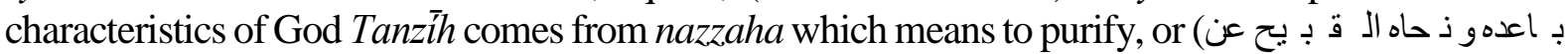
(ذ) sanctify it or keep it away from blemishes, so tanzîh: cleanses the likeness of the divine concept (elimination of anthropomorphic elements from the conception of deity).

\section{Wisdom qudusiyah (Purity) in the sentence about Idris}

The other names from Idris as are Akhnukh (Suryani), Thoth (Egypt), Hermes (Greece). In the hadith narrated by Ibn Abbas that Idris named Akhnūkh bin Yarid bin Mahlā'il bin Qaynān bin Anūsy bin Shí bin ibn Adam.

$$
\begin{aligned}
& \text { حدثني الحارث قال : حدثنا ابن سعد قال : أخبرني هشام قال: أخبرني أبي } \\
& \text { عن أبي صلاح عن ابن عباس قال : ولا أنوش قينان و نفرا كثيرا } \\
& \text { و إليه الوصية فولد قينان مهلائيل و نفر ا معهد إليه الوصية فولد مهلائيل } \\
& \text { يرد وهو اليارد و نفرامعه و إليه الوصية فولد يرد أخنوخ وهو } \\
& \text { إدريس النبي عليه السلام و نفر امعه فولد أخنوخ متوشلخ و نفرا معه } \\
& \text { و إليه الوصية فولا متوشلخ لمك و نفرا معه و إليه الوصية. }
\end{aligned}
$$

Telling me al-Haris said: telling me Ibn Sa'ad said: telling me Hisham said: told me my father: from Abi Salih from Ibn Abbas said: Anusy had a child named Qaynan and several others, and Anusy gave a will to Qaynan. Furthermore, Qaynan had the son of Mahlail and another child, then Mahlil had a son of Yarid and he was called al-Yarid and another child, and Mahlail gave a testament to Yarid. Yarid then had the son of Akhnukh or Prophet Idris as. and another child, and Akhnukh (Idris as.) had Matwasylikh's son and another child and Akhnukh (Idris as.) gave a will to Matwasylikh, then Matwasylikh had Lamak's son and another child, then Matwasylikh gave a testament to Lamak.

From the genealogy of Adam and his descendants, it appears that Akhnukh (Idris) is the $7^{\text {th }}$ generation of Adam. Idris in the Alquran is characterized by height : 
The point is the high position. When al-Haq ta ala has the name al-ulya, which is high, it means that lafazh is equally in height, but the height of Allah is not the same as the height of the creature. There is an altitude that is Z̄ătî there is also an idhāfí. The height of Zāâtí is the height of God, indeed the height is his. Whereas the height of idhāfin.is the height that is propped up, like humans, is called high because of its position.

\section{Wisdom of Muhammadiyah (closeness) in the sentence about Ibrahim.}

Ibrahim was the owner of the title al-khalil, because he had penetrated all the attributes of God, and had become God's favorite.

\section{Wisdom haqqiyah (truth) in the sentence about Ishaq.}

The prophet Ishak according to Ibn 'Arabí was the prophet who experienced Abraham's slaughter. In this phase Ibn 'Arabí wants to explain how the method of acquiring knowledge. Dreams are not knowledge. Dreams still need the means to interpret them as clues.

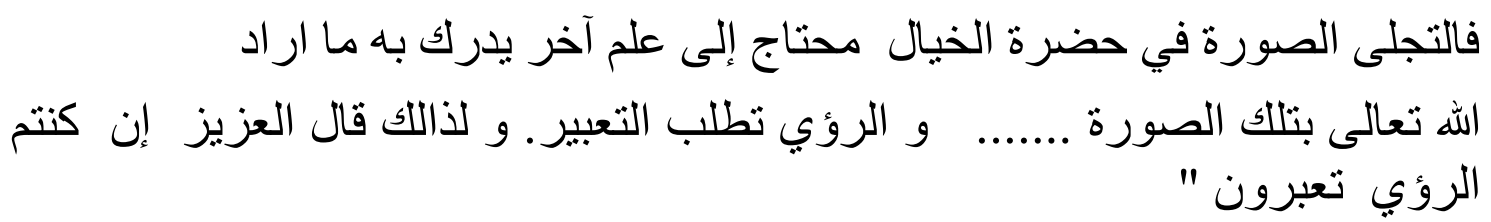

Dream is a matter of imagination, Abraham did not make it a clue, in this case Abraham obtained it from the heart (wahm). Appearance of forms in the natural world still requires other knowledge to know what God wants with that form. '

Ibn 'Arabí stated in this Fas that Abraham misinterpreted his dream when he dreamed that he slaughtered his child, because the state of sleep is within the scope of imagination that requires interpretation. This is what caused Allah to save his son from al-Zabh al-Azhim (the Great Victim), where Ibrahim did not realize it.

\section{The beauty lesson in the Word about Ismail.}

Ismail's existence according to Ibn 'Arabí is the existence of creator and creation. The creator loves his creation. Ismail is the product of Allah's creation, because of that Ismail was loved by Allah, loved by Him, because he was a truly delightful form of creation. Ibn 'Arabí wants to declare that servants are the product of Allah's creation, therefore I am pleased with Allah and Allah is pleased with my servants.

\section{Wisdom of Ruhiyah in the Word Ya kübiyah.}

Fas is taken from the expression $Y a{ }^{\prime} k u b$ to his son, $\mathrm{O}$ my son, that Allah has chosen for you religion. ' Religion is al-din, the meaning of al-'ädah, al-'aud, returns, returning to you based on what you do. Also called wisdom. Rauhiyah means again. God does not return to beings except on their terms. ${ }^{3}$

In this phase Ibn 'Arabí uses the sentence ruh, but he does not mention the discussion about the soul at all. The spirit that he means is religion, and $Y a^{\prime} \mathrm{kub}$ is the person chosen by the religion of Allah. Religion is the guideline, the people who develop it, God sets the law.

\footnotetext{
${ }^{3}$ al-Ghurab, Syarh Fușúș̣, p. 121.
} 


\section{Wisdom nuriyah (Light) in the Word about Joseph.}

Yusuf was appointed Ibn 'Arabí as the theme of how his popularity in good looks, so that women called him an angel. Angels also often disguise themselves as humans. It is interesting to see a scene because it is beautified with the imagination. Joseph saw his brother in the form of a star, father and aunt in the form of metahari and moon. Ya kub understood this vision so he told Yusuf to keep it a secret. That is the truth that we know from a great way.

\section{The Wisdom of Oneness in the Word about Hud.}

In this phase Ibn 'Arabí wants to explain the nature of shirathal mustaqim. Al-haq that is Shirathal Mustaqim. In the fas on Hud, Ibn 'Arabí expressed one of his inner experiences when meeting the Prophets, from Prophet Adam to Prophet Muhammad SAW. in Cordova in 586 H., but only Hud spoke to him. He saw Hud, a man who was handsome, handsome and with gentle words, and he said about the reason why they held the meeting.

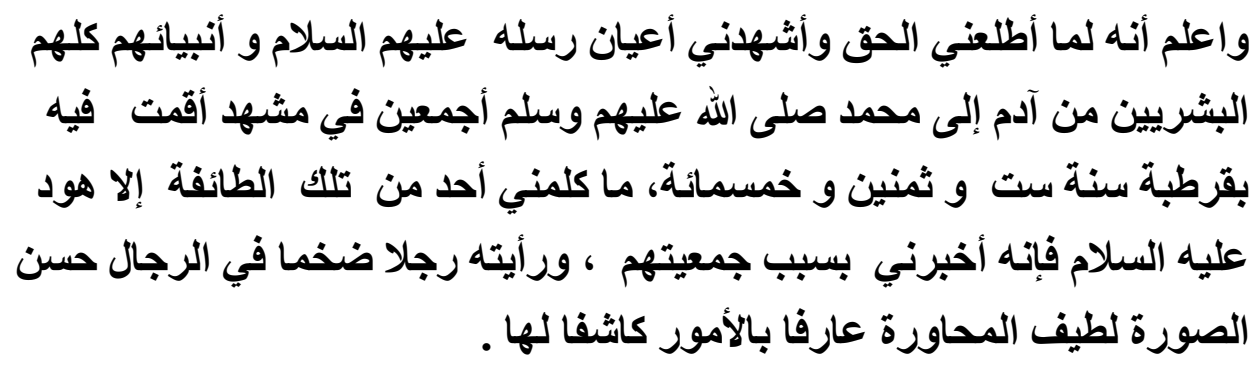

\section{Wisdom futuhiyyah (opening) in the sentence about Salih.}

In this phase Ibn 'Arabí wants to explain the occurrence of something through three stages or more, the first is the existence of something, the second is the essence of desire, and the third is the commandment. If God will make one afrad, then he will say be, then be it. The Munasabah concept three with Saleh is that Allah destroys his people in three days. The first day their faces were yellow, the second day their faces were red, and the third day their faces were black, that was an accident.

\section{Wisdom in the Word about Syu'aib.}

In this phase Ibn 'Arabí is included in the Sufi jargon which is the center of the orientation of their thinking, namely tajalli Allah. The heart is a container that is wide enough so that it is fit for Allah to worship. The heart of the wise from the mercy of Allah, the heart itself is wider than that grace. It is related to Syu'aib, because the 'tiqad has many syu'bah.

\section{Wisdom of Power in sentences about $L u t ̧$}

Power is power. Lut craved that power to sustain his apostolic duty which he called ruknin syadid. Rasulullah saw. say ruknin syadid is Allah. The purpose of Lut is a group (tribe) that supports it. So from that time the prophets were helped by his people, and the Messenger of Allah. assisted by his uncle. According to Ibn 'Arabỉ that power is ma'rifah.

\section{Wisdom of Destiny in the Word about ' $U$ zair.}

In this phase Ibn 'Arabí wants to establish religious understanding of qadha (provisions) and qadar (the occurrence of these provisions, destiny). Qadha is God's law of things. God's law on something according to Allah's knowledge on something. Destiny is the aspect of the time the provision occurs, without deviation. Destiny is unknown because it is very clear. Knowledge of 
destiny can be achieved by the knowledge of ma'rifah and prophethood. Prophetic knowledge is only given as much as the need to carry out tasks. But the secret of Allah's destiny is only told to the perfect person. Uzair wondered when crossing the Palestinian city that had just been destroyed by Bukhtanasar 'how would God bring this city to life after his death?' So God killed him for 100 years and brought him back to life after that. He witnessed a prosperous Palestinian city.

\section{Wisdom of Prophethood in the Word about 'Isa}

As for this Isa Ibn 'Arabí discussed the nature of life in the view of religion. Gabriel gave the source of life to Mary in the form of a child without the process of involvement of a man. Therefore Jesus can turn clay into a bird and the dead, because he is the soul of Allah. This event was a repetition in the time of Moses, where only traces of Jibril could be processed by Samiri to become a living cow, and Abi Yazid al-Busthami who revived the ants he had killed. ${ }^{4}$

\section{The Wisdom of Exaltation in the Word about Sulaiman}

Sulaiman was made a spotlight on the nature of Allah rahman and Rahim, because that is the name he wrote on the letter he sent to Balqis "this letter from Sulaiman, and this letter with the name of Allah who is most merciful". There are people who think Sulaiman called his name the name of Allah, this opinion is wrong. The proof is Balqis' words, 'the glorious book has been sent to me'. Their opinions were influenced by the events of the Prophet's surt. which was torn apart by Kisra. He does not burn it except after reading and knowing the whole contents.

Prophet Sulaiman was given two blessings, mercy and blessings and mercy of al-Wujub, namely al-rahman and al-rahim. However, the wujub is also part of faith, the womb has actually been contained in al-Rahman. According to Ibn Arabi man is the conclusion of the blessing of grace with the divine names and nasab rabbani. Then after human beings are manifested, the Wujub comes and explains that humanity is Him, so that He does not oblige Him except for Himself.

\section{Wisdom of Being in the Word about Daud.}

Nubuwwah and treatise are gifts, not the results of work performance and the demands of prayer. The prophets were all given gifts not as a charity in return, so was Daud, except that David was a blessing and ifdhal. The favors given to Daud include names that do not use continuous letters. From this name Ibn 'Arabí that the quality of Daud as its name is broken, shows no attachment to nature. While Muhammad used the combining the two conditions, continued to Allah and broke from the creatures.

Delicious to Daud was also a mountain with him as a deed for him, as well as birds. Also given him strength, wisdom, position as caliph, with wisdom he could decide the law without waiting for revelation. if God made the caliph on earth, Daud was the person, there was no other prophet who was sown as Khalifah, Daud was the substitute of Allah on earth and also the prophet. The Khalifah is now a substitute for the prophet.

\section{Breath of Wisdom in the Word about Yunus}

Among the fusus which were made as a stepping stone for understanding Ibn 'Arabí agama religion, what is unique is this $18^{\text {th }}$ fusus, where he presents the existence of Yunus in relation to lust, but apart from the title, Ibn' Arabí did not mention Yunus, even his story not.

${ }^{4}$ Ibn Arabi, Fușúus, p. 142. 
Ibn 'Arabí actually added to the story of the prophet Daud who built a house of worship many times but still collapsed, so Daud asked Allah why it happened like that. God replied that he did not want his house of worship to be built by bloodied hands. According to Ibn 'Arabí human existence in spirit, body, and lust must be protected, love for humans must take precedence over passion in godliness. This method is based on the teachings of religion how a person who becomes an enemy of religion is protected by paying jizyah, qishas experts can be released with the forgiveness of blood experts, if the blood expert agrees qishas except for one person, it turns out the legal alignment to him, and qishas according to the Qur'an is sayyiah. Does Ibn 'Arabí's point of view emphasize that if the Jonahs should have received a disaster because of their opposition, Yunus should not have allowed them to receive a painful punishment and he had escaped by running away from his village which had been shaded by a cloud of disaster? Perhaps also the wisdom contained in the story of Yunus is from the expression that the person who remembers is accompanied by what he remembers, and witnesses whatever he does.

\section{The Unseen Wisdom in the Word about Ayyub}

The story of Ayyub teaches the method of religion how important water is. Life flows with water, water becomes the source of life, from water is made into everything that lives, everything is life, everything that lives exalted to Allah, only we do not know how the rosary is, except the person who is opened by the Divine Word. It turned out that the Throne was placed by God on the water. Humans have six directions, top, bottom, left and right side, and back face. God is in all directions, and feeds from above and below the feet of men. Because humans are formed based on the shurah al-rahman they have six directions.

Allah is the beginning with meaning, ending with shurah, zhahir because it changes the law and circumstances, the mind because it is he who makes the planning. Knowing everything, also watching it, not thinking about it. Likewise zuq science, not the science of thinking.

Ayyub suffered from a disease which was a demonic sting, namely al-bu'du' an alhaqaiq, knowing the essence according to what he was, while syuhud was close to the eye even though it was far away. Far and near it is only a sign that there is no form. Job was praised by Allah for his patience and prayer to lift his suffering. Praying does not destroy patience, because it returns it to God not to cause. Patience is not refraining from complaining about self, but refraining from complaining to other than Allah, not to Allah. The wise person is not veiled because of his request to Allah.

\section{Wisdom of Glory in the Word about Yahya}

Yahya is the special name chosen by Allah for Yahya, whose meaning revives. Yahya is the one who revives Zakaria remembrance, as Adam revived his remembrance with the Syits, Nuh revived his remembrance with Sam, as well as the others anbiya'. All of the prophets his father's gave the name, then the name was chosen as a good hope for the nature, but there was nothing to be combined between the name and nature at the same time except to Zakaria as the blessing of his prayer 'hab li min ladunka waliyya', so he got the child Allah himself who chose the name for him. According to Ibn Arabi the child is the secret of his father.

\section{Wisdom of Mastery Lessons in the Word about Zakariyya}

Fas about Zakariyya according to Ibn Arabi is a matter of substance and character. God's grace includes all its forms and laws. The form of wrath from His mercy with anger. Divine names are things, which return to one substance. Grace in creation is very broad. People who 
have knowledge are called pious, pious things. The pious people are those who are sympathized with knowledge. That attribute is in Him, that trait is not a substance other than that.

Here Ibn Arabi uses the Sunni method in placing between matter and character. God's grace according to Ibn Arabi can be obtained by two ways, the wujub road and the al-imtinan al-ilahi. The way of wujub is "I will give My mercy to those who are cautious and tithe". Whereas the second path is solely a divine gift "My mercy covers all things", "so that Allah forgives you what was before from your sin and what is later", and "do what you want then in fact I have forgiven you".

\section{Wisdom of Closeness in the Word about Ilyas}

Ilyas is a symbol of reason without lust. Reason can know Allah with tanzih, not with tasybih. In humans there is the power of reason, there is the power of understanding. The dominant is the power of understanding, but easy to lose. This is where the Shari'a is revealed. Similar in holiness with wisdom and holiness in that likeness to reason. There is nothing like Him - it is tanzih - and He is all listening and all-seeing - is liking. Holy of your Allah from what they characterize - what people characterize is based on their reason. While a person who does not have faith sets the law of understanding and understanding, he is imagined with a view of thought.

In the view of Ibn Arabi Idris was a prophet who was sent before Nuh, then Allah was appointed to heaven, then revealed again as the prophet Ilyas. According to Afifi, Ibn Arabi talked about the Prophets not as a historical figure known as the Shari'a, but as a psychological quality in dealing with divinity. Idris identified Afifi as Hermes who had many books on science. Hermes is a figure of mind that is not bound by the body so that it is utterly defeated to Allah. Idris is an interpretation of the human body that is full of desires and lust. The fire horse that was his mount was the body's lust and desire. Whereas Ilyas is a symbol of the release of humans from their lusts. Whereas according to al-Ghuram, Ibn Arabi does believe there are four human figures that continue to live, namely Idris, Ilyas, Isa, and Khidr, which he mentions directly on Futuhất al-Makkiyah.

\section{Wisdom of Good in the Word about Luqman}

Wisdom is a lot of goodness. The name al-hakim in the Qur'an is always accompanied by the names al-alim and al-khabir. The judge is pious about khabir. Issues that are tasteful. Ihsan is a feeling, the Messenger of Allah. say 'you worship Allah as if you see it, if you don't see Him really He sees you'. From this statement, there are two, first, as if you saw Him. The second is the higher-than-one person, as if, someone can see Him. Both are flavors, therefore, wisdom and ihsan can unite in taste. This is the munamar between the wisdom given to Lukman with ihsan in zauq so that Ibn Arabi gave him the title of hikmah ihsaniyah in the luqmaniyah sentence.

\section{Wisdom of Imamiyah (Leadership) in the Word about Harun}

Harun was a priest, not a khalifah, only a substitute for the Khalifah, Musa, so Harun did not have any middle rights. According to Ibn Arabi Musa was indeed younger than Harun, but was older in prophetic terms. Harun received revelations only to support Musa. Prophet who are recipients of the Shari'a are not the same as the zauq pattern with the prophet who did not receive revelation, so the prophet is not the same as the guardian. Thus the zuq level is not the same from the expert ma'rifah. 
When Musa accepted the book, it was Harun who accompanied his people. They then worship the calf, Harun must wait for Moses for the matter. When Harun recounts the deviations of his people, Musa responds angrily and draws Harun's hair, so that Harun calls him $\mathrm{O}$ my mother's child, pitying for mercy. Because mother is a symbol of love. Therefore the concept of love was taught by Allah through the events of Harun and Musa.

\section{Wisdom of Height in the Word about Musa}

Musa is characterized by high wisdom according to al-Ghurab because Ibn Arabi highlights the existence of the history of Musa. Pharaoh called himself high, I am your highest Allah. When a sorcerer makes a great appearance of a snake, Moses is rather afraid, then Allah says 'do not be afraid, you are indeed higher.

The presence of Musa began with the death of many children of the Children of Israel, whom they died because of Musa. So Musa was a mixture of all of these spirits, and this only happened to Musa, not to other Prophets. This is an effective start on how the little ones manage the big ones, like little ones regulating the behavior of big people because of their strong position, so that big people work for them. Likewise nature is subject to human will.

\section{The wisdom of eternal in the word about Khalid}

It is called the wisdom of shamadiyah (eternity) because Khalid bin Sinan hopes to be able to tell his people about the life and knowledge of barzakh given to him. Barzakh is the place of return of the law of all hadharat al-wujudiyah. Khalid bin Sinan is a prophet who is not an apostle whose time is not far from the prophethood of Muhammad, therefore he is not obliged to behave high, except to answer questions.

Ibn Arabi raised the history of Khalid bin Sinan to respond to the barzakh problem. Knowing the barzakh realm is after death. He hoped his people would ask him about barzakh's life that life in barzakh was the same form as life in the world. Khalid knew the truth of the teachings of the apostles when they lived in the world. If everyone believes what the apostles teach, it will bring mercy to all beings. ${ }^{5}$ When there was a fire burning Abbas's village, they came to Khalid bin Sinan. Khalid then took each one of the Abbas tribes one person with a whip and walked to the fire. From the fire came the shoulder of a camel and then in the libas with the fire extinguished the fire. He then went to the cave and preached his death, after which they had to take his body so that he could tell what happened in the barzakh realm. But his people ignored him. The wisdom of unity in the word about Muhammad

\section{Conclusion}

Ibn 'Arabí is an Arab thinker, raised in Spain, living in the Sunni Maliki environment, far from the Syi'i influence. As a student who likes to search for knowledge of Ibn 'Arabí, he appears to be raised in free scientific manners, without being tied to a narrow doctrine so that all the patterns of thought that have developed previously have been very well studied, and picked up the truth that he found there, then combined them with revelation existing ones.

In shaping Ibn 'Arabí's my tasawuf, he moved from the verses of the Qura'an and the Sunnah of the Prophet with an external interpretation approach, such as the form of Allah, the blowing of spirits, the existence of Allah in nature and all beings, while the Sunni scholars

\footnotetext{
5 Ibn Arabi, Fușủș, p. 214.
} 
must do the verses - the story. Even so, Ibn 'Arabí was not a group of mujassimah and salafiyah who personified Allah. Ibn 'Arabí

Ibn 'Arabí has nothing at all to carry the name and opinion of a philosopher or figure both Islamic and outside Islam in initiating his thinking. Even if he mentions the name or the name of one character in order to reject their opinion or compare it with the results obtained. For Fusus al-Hikam Ibn 'Arabí to prove that the book was indeed given by the prophet directly to him.

The thought of Ibn 'Arabi clearly had a significant influence on tasawuf afterward. This is indicated by the spread of Ibn 'Arabi's work which was translated in various languages, such as Turkish, Persian, Arabic, English, and Malay, both in the form of poetry, poetry, essays and so on. There are hundreds of writings that discuss and judge Fu al-Hikam, one of which is Syarh Fușús al-Hikam from Manla Abdurrahman al-Jami (d. 898 h), referring to Khalifah sufiah Bali Afadi (d. 960 H), and syarh syekh Arif Billah Abdul Ghani an-Nabulsi (d. 1143 H).

\section{References}

A. Mustofa, Filsafat Islam, Bandung: CV Pustaka Setia, 2007.

Abdurrahman ibn Khaldun, Muqaddimah, Mesir : Dar al-Fikr, th.

Abu al-A'la Afifi, Filsafat Mistis Ibn `Arabi, terj. Sjahril Mawi dan Nandi Rahman dari A Mystical Philosophy of Muhyiddin Ibn `Arabi, Jakarta: Gaya Media Pratama, 1995.

Abu al-A'la Afifi. The Mystical Philosophy of Muhyi 'Din Ibn 'Arabí . Cambridge : University Press, 1939

Abu al-Ala Afifi, al-Ta liqāt Fușứṣ al-Hikam, Beirut: Dãr al-Kitab al-'Arabi, tt.

Abu al-Fadhl. Syarh al- Kawākib al-Lamā’ah. t.tp: Maktabah al-Hidāyah :tt

Abu al-Wafa`al-Taftazani, Sufi Dari Zaman Ke Zaman, terjemahan Ahmad Rofi` Bandung: Pustaka, 1997.

Al-Hakim, Su'ad. al-Mu'jam al-Sufi : al-Hikmah fi Hudud al-Kalimah. Beirut: Dandarah, 1401 $\mathrm{H}$

Ali Abd al-Raziq, al-Islâm wa Usûl al-Hukm al-Khilâfah wa al-Hukumah fi al-Islam, Tpk : Tp, 1925

Amien Rais, Tauhid Sosial, Bandung : Mizan, 1998

Amir Syarifuddin, Prof. Dr. Meretas Kebekuan Ijtihad, Jakarta : Ciputat Press, 2002

Arskal Salim dan Azyumardi Azra (ed), Shari'ah And Politics in Modern Indonesia, Singapore : Institute of Southeast Asian Studies, 2003.

AS Hornby. Oxford Learner's Dictionary of Current English .Walton Street, Oxford : Oxford University Press, 1994.

Coulson, N.J., A History of Islamic Law, . Edinburgh : University Press, 1994.

Crone, Patricia, The Rise of the Islam in the World. Dalam "The Cambridge Illustrated History of the Islāmīc World" Ed. by Francis Robinson, Cambridge : University Press. 1996.

Departemen Agama Republik Indonesia. Alquran dan Terjemahnya. Semarang : Toha Putra, 1979

Farghani, Sa'id Ibnu Muhammad. Masyāriq al-Darāri. Teheran : Mawla, 1368 H

Fazlurrahman, The Islāmīc Concept of State, dalam Islam in Transition Muslim Perspectives, edited by John J. Donohue and John L. Esposito, New York, Oxford : Oxford University Press, 1982. 
Fyzee, Asaf AA, The Reinterpretation of Islam, dalam Islam in Transition Muslim Perspectives, edited by John J. Donohue and John L. Esposito, New York Oxford University Press, 1982.

Ghanī, Muhammad Ilyās 'Abd al-, Tārīkh Makkah al-Mukarramah Qadīman wa Hadītsan. Riyād : Dār al-Nahdah, 2003.

Glubb, Jhon, The Life and Times of Muhammad, Maryland : Madison Book's, 1998.

Goldziher, Ignaz, Introduction to Islamic Theologi and Law. New Jersey : Princeton University Press, 1981.

Gottschalk, Louis, Mengerti Sejarah, terjemahan Nugroho Notosusanto Dari 'Understanding History, A Primer Historical Method', Jakarta : UI Press, 2006.

Grunebaum, G.E. von, Classical Islam A History 600 A.D.-1258 A.D. Chicago : Aldine Publishing Company, 1970.

Haikal, Muhammad Husain, Hayatu Muhammad, Riyād: Maktabah al-Rusyd, 1997.

Hammad ibn Muhammad, Abu al-Hasan al-Asy`ari, Beirut : Dar al-Kutub al-Ilmiyyah, cet. I, 1998.

Hans Wehr. A Dictionary of Modern Written Arabic. Edinburgh : J. Milton Cowan, 1960

Harun Hadiwijono.Kebatinan Islam Abad XVI. Jakarta : Gunung Mulia, tt

Hasan, Ahmed, Theorician Early Development of Islāmīc Jurisprudence. India : Adam Publisher \& Distributors, 1994.

Hasan, Ibrahim Hasan, Tarikh al-lslām. Qāhirah ; Maktabah al-Nahdah al-Misriyyah, 1979.

Hasanuddin AF, dkk. Pengantar llmu Hukum. UIN Jakarta Press, 2004.

Hasballah, 'Ālī, Usūl al-Tasyrī' al-Islāmī. Mesir : Dār al-Ma'ārif, 1391/1971.

Encyclopedia of The Modern Islamic World, New York : Oxford University Press, 1995

Louis Ma'luf . al- Munjid fi al-Lughah wa al-A'lam. Beirut : al-Maktabah al-Syarqiyah, 1986

M. Quraish Shihab, Wawasan al-Qur'an, Bandung: Mizan, 1996

Ma`ad al-Hakim, Ibn 'Arabi Maulid Lughatin Jadîdin Beirut: Al-muassasah al-jamiiyyah li alDirasat wa al-Nasyr wa al-Tauzî’, 1991.

Mahmud Mahmud al-Ghuram, Syarh Fușứș al-Hikam, Maktabah Zaid ibn Tsabit, 1985.

Muhammad al-Kaus, al-Wajiz fi asma al-Husna, Beirut, Lubnan: Dãr al-Kitab al-'Arabi, tt.

Sayyid Husain Nashr, Tsalãtsat Hukamã Muslimîn, Beirut : Dãr al-Nahãr, tt..

Seyyed Hossein Nasr. Three Muslim Sages. Delmar NY, Caravan Books, 1975.

Simuh, Tasawuf Dan Perkembangannya Dalam Islam, Yogyakarta: Islamika 1996.

Tirmidzi, Muhammad ibn 'Isa Abū 'Isa al-Salmī al-, Sunan al-Tirmidzi. Beirūt: Dār al-Ihya' alTurāts al-'Arabi, 1980.

Toshihiko Izutsu. The Concept and Reality of Exixtence Tokyo : The Keio Institute of Cultural and Linguistic Studies, 1971

Tūfì, Najm al-Dīn al-, Syarh al-Arba'īn al-Nawāwiyah. Mesir : Dār al-Kitāb al-Jamrah, 1983.

Turabi, Hasan al-, Tajdid al-Fikr al-Mami, Mesir : Dār al-Kutub, 1975.

'Umari, Akram Dhiya' al-, Madinan Society at the Time of the Prophet. Riyadh : al-Maktabat, $1382 \mathrm{H}$.

Watt, William Montgomery, Muhammad's Mecca, History in the Qur'an, Edinburgh : Edinburgh University Press, 1988.

Wehr, Hans, A Dictionary of Modern Written Arabic, Beirūt: Libraire du Liban, 1974.

William C.Chittick. The Sufi Path of Knowledge: Ibn al-'Arabî's Mataphysics of Imagination. Albany : State University of New York Press, 1989. 
Zaidan, George, History of Islāmīc Civilization, Translated by D. S. Margoliouth, New Delhi: Kitāb Bhavan, 1978.

Zakaria ibn Muhammad ibn Zakaria al-Ansari Abu Yahya, al-Hudūd al-Anīqah wa al-Ta'rifāt al-Daqīqah. Beirut : Dār al-Fikr al-Mu'āsir, 1411

Zarkasyi, Muhammad ibn Bahadur ibn 'Abd Allah Abū 'Abd Allah al-, al-Burhān fī 'Ulūm alQur'ān. Beirūt: Dār al-Ma rifah, 1931 H.

Zarqa', Mustafā Ahmad al-, Al-Fiqh al-Islāmī fî Tsaubihi al-Jadīd. Damaskus : Dār al-Fikr, 1968. 